\title{
J(৫)
}

Received: 03.05.2019

\section{Çağatayca Tefsir-i Hüseynî (Mevahib-i Aliyye) Tercümesi ve Farsça Dil Özellikleri Üzerine}

\section{On the Translation of Tafsir-i Husaynî (Mavahib-i Aliyya) in Chagatai Turkic and Persian Language Features}

\author{
Saidbek BOLTABAYEV \\ Karabük University (Zonguldak/Turkey) \\ E-mail: saidbekboltabayev@gmail.com
}

After the acceptance of Islam by Turks, the need for translations and tafsirs of the Qur'an increased so that the Turkish works of this kind multiplied. Some of the Qur'an translations and Turkic tafsirs are copyrighted works while some others are translated works. In this article, the Persian language properties which are seen in the work which is well known as the Chagatai Turkic Quran tafsir have been determined and it has been revealed that the tafsir is the translation of the Mavahib-i Aliyya (also known as Tafsir-i Husaynî) written in Persian.

Key Words: Qur'an, Tafsir, Exegesis, Persian, Chagatai Turkic, translation, Husayn Waiz Kashifi. 


\section{J(G)}

\section{Giriş}

Türk kavimleri için her zaman dinî edebiyatın ayrı önemi olmuş, bağlı oldukları dinin esaslarıyla ilgili çok sayıda eser kaleme almışlardır. İnandıkları dinin kutsal kitabının yazıldığı yazı sistemini Türkçeye uyarlamışlar, telif ve tercüme eserler oluşturmuşlardır. Bu durumu Türkçe Budizm, Maniheizm, Hristiyanlık muhitinde yazılan metinlerde gördüğümüz gibi İslam dönemi eserlerinde de gözlemliyoruz. İslamiyet'in Türkler tarafından kabul edilmesinden sonra Kur'an tercümeleri ve tefsirlerine duyulan ihtiyaç artmış, böylece bu türde yazılan Türkçe eserler çoğalmıştır.

Türkçe Kur'an-1 Kerim tercümeleri ve tefsirlerinin bazıları telif eser, bazıları da çeviri eserlerdir. Çeviri eserler genellikle Farsçadan Türkçeye tercüme edilmiş Kur'an tercüme veya tefsirleri olarak karşımıza çıkmaktadır. Telif eserlerde ise Farsça eserlerin de geniş bir şekilde kaynak olarak kullanıldığı dikkat çekmektedir. Ayrıca ilk dönem Türkçe Kur'an tercümelerinden olan satır-arası Meşhed (No: 2229), İngiltere Rylands (No: 25-3821) ve Özbekistan (No: 2008) nüshaları Türkçe ve Farsça şeklinde iki dilli tercüme olarak kaleme alınmıştır. Bütün bunlar yüzyıllar boyunca komşu olan Türkçe ve Farsçanın dinî edebiyatta etkileşimini göstermektedir.

\section{2. Çağatayca Tefsir-i Hüseynî Tercümesi}

Çalışmamıza konu olan eser bilim dünyasında Çağatayca Kur'an Tefsiri, Doğu Türkçesi Kur'an Tefsiri, Topkapı Sarayı nüshası gibi çeşitli isimlerle anılmaktadır. Çünkü ne eserin nüshalarında ne de dönemin diğer dinî kaynaklarında tefsirin müfessiri, yazıldığı yeri ve yılına ilişkin herhangi bir bilgi bulunmamaktadır. Bu sebeple bugüne kadar yapılan çalışmalarda eserin müfessiri ve yazıldığı tarihi ve yeriyle ilgili belirtilenler birer tahmin mahiyetindedir.

Eserin üç nüshası mevcut olup ilk önce İNAN tarafından Konya nüshası, daha sonra ECKMANN tarafından Topkapı nüshası tanıtılmıştır. Eser dilinin klasik ve ağır Çağatayca olduğunu belirten İNAN, yazarın adının olmamasından dolayı tefsirin yazıldığı tarihi tayin etmenin güç olduğunu, ancak üç yerde geçen Şeyh Ubeydullah kaddese allahu sirrehü ifadesinden hareketle 1490 yılından sonra yazılmış ol- 


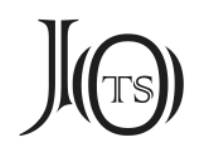

ması gerektiğini, bu dönemde Özbek Şeybanî soyunun Türkistan'da egemen olduğundan dolayı Türkçeye büyük önem veren Ubeydullah Han'ın hükümdarlık yıllarında yapılmış olabileceğini vurgular (1962: 61).

ECKMANN ise Çağatayca Kur'an tefsirinin XVI. yüzyılın ilk yarısında Şeybanîler devrinde meydana getirildiğini, ayetlerin kelime kelime çevirilerinin ise daha eski Doğu Türkçesi Kur'an tercümelerinin tesiri altında olduğunu belirtir (1967: 53).

Eser üzerinde doktora tezi hazırlayan ZÜLFiKAR gerek Timurlular gerek Şeybanîler döneminde Semerkant ve Herat'ın birer kültür yuvaları olduğundan eserin muhtemelen Herat'ta kaleme alınmış olduğunu, Kur'an tefsiri yazacak kadar din eğitimi gören Ubeydullah Han'ın bizzat kendisi veya onun teşviki ile eski dile bağlı biri tarafından ve bir orijinal nüshaya dayanılarak yazıldığını belirtir (1974: 179).

Daha sonra eser üzerinde yüksek lisans çalışmaları yapan İbrahim TAŞ (2001), Emine Temel (2013), Dursaliye ÇAĞLAR (2013), Hülya Şen UzunoĞLu (2015), Kübranur KURTOĞLU (2015), Yurdagül Aydın ÜNGöR (2015), Gülşen Arslan PEKGÖZ (2016) de bu görüşleri desteklemiştir.

Ancak tefsir üzerinde dil incelemesi yaparken elde ettiğimiz tespitler sonucunda eserin Farsçadan Çağatay Türkçesine tercüme edildiği, müfessirinin Hüseyin Vaiz Kaşifî olduğu, Tefsir-i Hüseynî adıyla da anılan tefsirin adının ise Mevahib-i Aliyye olduğu ortaya çıkmıştır. Tefsirin dilinde belli başlı Farsça özelliklerin belirgin olarak bulunmasının dikkat çekmesi neticesinde bu tespit elde edilmiştir.

Eserde görülen Farsça morfolojik ve sentaks özellikleri şöyle sıralayabiliriz:

\section{Birlik ve Belirsizlik ya'sı}

Farsçada kelimenin sonuna gelen birkaç çeşit ya (ى) harfi vardır. Bu ya'ların hiçbiri vurgulu olmayıp uzun $̂$ şseklinde telaffuz edilmektedir. Tacik ve Derî Farsçasında ise kapalı é şeklinde telaffuz edilmektedir. Metinde bu tür ya’ların belli başlı çeşitleri kullanılmıştır. En çok kullanılan çeşitlerinden biri birlik ve belir- 


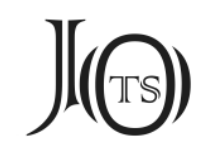

sizlik ya'sıdır. Birlik ve belirsizlik ya'sı kattığı anlam açısından birbirinden farklıdır. Birlik ya'sı eklendiği kelimenin miktarını bildirir, onun bir olduğunu, tekliğini vurgular. Belirsizlik ya'sı ise eklendiği kelimenin belirsiz olduğunu bildirir. Eserde görülen örnekleri aşağıdadır:

Ādamînin éski ve boş bolġan sümekini hażrat-1 payġambar șallallāhu 'alayhi ve sallamġa kéltürdi. "Bir kişinin eski ve boş olan kemiğini hazret-i Peygamber'e (sav) getirdi." (267a/7)

Büzürgîdin sordılar. "Bir ulu kişiye sordular." (232b/27)

Mén bu tağda gāâi bilürmén. "Ben bu dağda bir mağara biliyorum." (297a/10)

Birlik ve belirsizlik ya'sının metinde Türkçe kelimelere de gelebildiği görülmektedir. Böyle durumlarda hâl ekleri ve bildirme eki birlik ve belirsizlik ya'sından sonra gelmekte ve imlada ayrı yazılmaktadır:

Eger éşikîni baġlasa özgeni açar. "Eğer bir kapıyı kapatırsa, başkasını açar.” (186b/1)

Hîç işîve sözî hak subhānaġa örtüglüg yoktur. "Hiçbir iş ve hiçbir söz her türlü noksandan uzak olan Allah'ın huzurunda gizli değildir.” (212b/3)

İhlāṣ tüz yolîdür méniy sarıġa. "İhlas benim tarafıma doğru bir yoldur." (263a/25)

Yllîde on bir künge ta yîndür. "Bir yılda on bir güne tayin olur." (300a/12)

\section{4. İşaret ya'sı}

Farsçanın sentaks yapısı birleşik cümlelerin çok sık kullanılmasına elverişli olduğu için bu tür cümlelerin birkaç şekli vardır. Ki bağlama edatı ile bağlanan birleşik cümlelere ki'li birleşik cümle denir. Böyle cümleler iki veya ikiden fazla cümleden oluşur. Ki'li birleşik cümlede bir ana cümle, bir veya birden fazla yardımcı cümle bulunur.

Metnimizde ki'li birleşik cümle yerine kim'li birleşik cümle kullanılmaktadır. Türkçede ana ve yardımcı cümleleri birbirine bağlayan bağlama edatları Uygurlar döneminde Türkler yerleşik hayata geçtikten sonra ilk karşılaştıkları Soğd ve Tohar gibi İran kavimlerinin dillerindeki yardımcı cümle bağlayıcıları kısmen taklit edilerek alınmış ve Türkçede zaten var olan kaçan, kanyu, kim, ne gibi keli- 


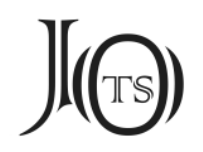

melere de bu bağlayıcıların anlamları yüklenerek kullanılmaya başlanmıştır (Tekin 1992: 112). ERGiN’e göre Uygur Türkçesi döneminden itibaren kullanılmaya başlanan kim, Türkçe soru zamiri olan kim'dir ve o dönemden beri kullanılan kim'li birleşik cümleler, zamanla artmıştır. Eski Türkçedeki kim ile Farsçadaki ki benzerlik kurmuştur ve dilimizde kim, ki yerine kullanılmaya başlamıştır (2000: 332).

Türkçenin sentaksına aykırı olan ki'li birleşik cümlelerin her zaman Türkçe cümle yapısına uydurulması mümkündür. YeLTEN bu konuda Türkçenin zengin zarf-fiil ve sıfat-fiil sistemine sahip olmasının, ana düşünce etrafında birleşen yardımcı cümlelerin, en karışık ifadelerin tek yüklemle, sade cümleler içinde toplanmasına imkân sağlayacağını belirtmiştir (2005: 47).

Ki'nin ana ve yardımcı cümleler arasında doğrudan ilgi kurduğu durumlarda yardımcı cümle ana cümleye özne, nesne, yer tamlayıcısı, zarf gibi fiile bağlı birimlerden biri göreviyle katılabilir. Ki’nin bir cümle ile kelime arasında ilgi kurduğu durumlarda da yardımcı cümle bir sıfat hükmünde ve ana cümlenin çeşitli unsurlarının niteleyicisi olur (Yelten 2005: 47). Yardımcı cümlenin sıfat hükmünde olup ana cümledeki bir unsurun niteleyicisi olduğu durumlarda ana cümledeki nitelendirilen unsura Farsçada bir ya (ى) harfi gelir ve buna işaret ya'sı denir. Bu tür cümleleri niteleyici yardımcı cümleli ki'li birleşik cümle olarak tanımlayabiliriz. İsmail BANGi işaret ya'sını da belirsizlik (nekere) ya'sı olarak tanımlamaktadır (1971: 78).

\footnotetext{
Metnimizde bu tür niteleyici yardımcı cümleli ki'li birleşik cümlelerin Farsça cümle yapısına uygun olarak işaret $y a$ 'sıyla birlikte kullanıldığı görülmektedir. Bu tür cümleler "o" ve "öyle" zamirleri ile Türkiye Türkçesine çevrilebildiği gibi, sıfat-fiiller yardımıyla da Türkçenin sentaksına uygun hâle getirilmesi mümkündür. Eserde epey miktarda bulunan ișaret ya'sından bazı örnekler aşă̆ıdadır:
}

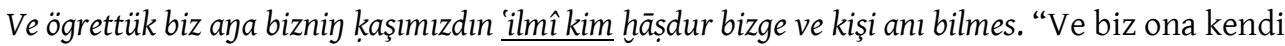
huzurumuzdan bize has olan, kimsenin bilmediği ilmi öğrettik” (304b/18)

Ve alargadır āhıratda pāyanda 'azābî kim üzülmeklik tapmas. "Ve onlara ahirette bitmek bilmeyen azap vardır." (193a/20)

Bildirme ve hâl eklerinin kullanıldığı durumlarda Farsçada olduğu gibi işaret ya's1 eklerden önce gelmektedir: 


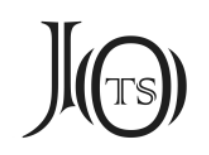

Her-āyina yaruk bélgüleridür qurūhiga kim tafakkür kılġaylar anda. "O konuda tefekkür edecek topluluklar için mutlaka açık delilleridir." (248a/16)

Hak subhāna nazar ḳlg̀ay kitābịde kim andın özge hîç kişi anda naz̧ar ḳlmas. "Her türlü noksandan uzak olan Allah, Ondan başka hiç kimsenin bakamayacağı kitaba bakar.” (235b/19)

Çokluk eki ise Farsçada olduğu gibi işaret ya'sından önce gelmektedir:

Āyatlarî kim sizlernin mațlūbınızdur vākii bolur. "Sizlerin istediğiniz deliller meydana gelir." $(206 b / 26)$

Yukarıdaki örneklerdeki kim'li birleşik cümlelerde işaret ya'sı alıntı kelimelerle kullanılmıştır. Ancak metinde hatırı sayılır miktarda Türkçe kelimelerle birlikte de işaret $y a$ 'sının kullanıldığı görülmektedir:

Korkunçi kim düşmandın alarnı köglige yétse yétmiş hasana alarnı dîvānıda bitürler. "Düşmana karşı olan korku onların gönlüne ulaşırsa yetmiş iyi amel olarak onların defterine yazılır." $(202 b / 7)$

Ey kök kayta al sû̂ kim tüben koyup sén. "Ey gök, aşağıya yağdırdığın suyu geri al!” (223b/24) Her türlüg yahşlligî kim kıla alursén kavlan ve filan halkka ḳlgaay sén. "Söz ile ve fiil ile yapabildiğin her türlü iyiliği halk için yapacaksın.” (277a/19)

Kim’li birleşik cümlelerde Türkçe kelimelerle işaret ya'sının kullanıldığı durumlarda Farsçada olduğu gibi hâl ekleri işaret ya'sından sonra, çokluk ekleri ise işaret $y a$ 'sından önce kullanılmaktadır.

Ve korkutḳl kişilerni kündüzîdin kim kélgey alarg̉a 'azāāb. "İnsanları onlara azap geleceği gündüzden korkut." (259b/21)

Ohşattı dünyā zindagānlıgiıı otige kim yamğur suyıdın kökerür. "Dünya yaşamını yağmur suyundan yeşeren bitkiye benzetti." (302a/21)

Ve yād ḳl künîni kim sürerbiz taġlarnı. "Dağları süreceğimiz günü hatırla.” (302b/10)

Anı köglekinin éteki taşigia kim kuyuk başıda édi asıldı. "Onun gömleğinin eteği kuyu başında olan taşa asılı kaldı." (235a/12)

Nacāt bérdük biz hūdka ve ol kisilerîge kim îmān kéltürüp érdiler. "Biz Hud'a ve iman getirmiş olan kişilere kurtuluş ihsan ettik." (225b/5) 


\section{J(৫)}

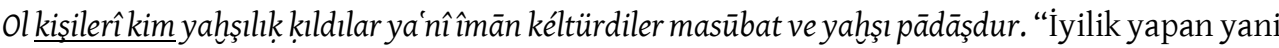
iman eden o kişilere iyi mükâfat ve ödül vardır." (208a/23)

İşaret ya'sının Türkçe kelimelerde sıfat-fiil eklerinden sonra geldiği de görülmektedir.

Ve çıkarurbız her ādamî üçün kıyāmat küni bitilgenî kim anıy 'amalını șahîfasıldur. "Kıyamet günü her insan için kendi amelinin defteri olan yazıyı çıkaracağız." (284a/1)

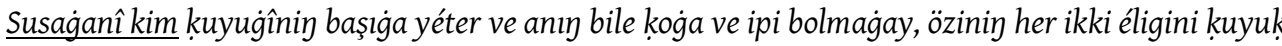
sariga açar ve faryād ve zārîlig ve du'ā bile sunı tiler. "Bir kuyunun başına gelen ve kendisiyle kova ve ipi olmayan susamış kişi iki elini kuyu tarafına doğru açar ve ağlayıp sızlayarak feryat ve dua ile su diler." (250a/9)

Yukarıdaki cümlede hem belirsizlik hem de işaret ya'sı Türkçe kelimelerde Farsça anlamıla kullanılmaktadır.

\section{Mastariyet ya'sı}

Bir isimden başka bir isim türetmek için kullanılan ya (ى) yapım ekine mastariyet ya'sı denir. Türkçe karşıllı̆ı isimden isim yapan \{+lik\} ekidir. Metinde alıntı kelimelerin mastariyet ya'sı ile birlikte kullanıldığı görülmektedir:

Hudāynın ni'matlarını kim sizlerge arzānî tutuptur sanay almassızlar. "Size uygunluk veren Allah'ın nimetlerini sayamazsını.." (268b/3)

Mastariyet ya'sının Türkçe kelimelere de geldiği görülmektedir:

Çıkıp kélür alarnı ḳursaḳlarıdın lu’āb țarị̂i bile içmekî ya'nî bal. "Onların midelerinden salya yoluyla içecek yani bal çıkar.” (273b/1)

Ḳıġançlıgîi ḳıldılar aya ve hudāynıy hakı̣ıı bérmediler. “Onu kıskandılar ve Allah'ın hakkını vermediler." (194b/18)

Farsça kelimeye gelen isimden isim yapan mastariyet ya'sından sonra tekrar Türkçe \{-lıg\} isimden isim yapma ekinin kullanıldı̆̆g durumlar göze çarpmaktadir:

Pes anıy madadkārîlığı bile Yūsuf'nı ḳuyuḳdın çıkardı. "Sonra onun yardımcıllığı ile Yusuf'u kuyudan çıkard.." (235b/21)

Hudāy aya yārîlıg ḳılġay. “Allah ona yardım edecek.” (188b/26) 


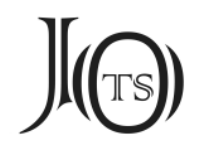

'Acz ve sınukluk ve zārîlığ anıy dar-gāhıg̉a élteliy. "Acizlik ve boyun eğme ve ağlayıp sızlamalarımızı Onun dergâhına ulaştıralım.” (271b/2)

\section{Kalıplaşmış ya'lar}

Ki'li birleşik cümlelerin çeşitlerinden olan zarf yardımcı cümleleri, ana cümlenin yükleminin zamanını, eylemin ne şekilde, ne zaman, hangi vasıta ile ve niçin yapıldığını veya olduğunu bildirir. Ana cümledeki hareketin zamanını bildiren yardımcı cümlelerde metnimizde çün, vaḳtî kim, tā vaḳtî kim bağlama vas1taları kullanılmaktadır. Vaktî kim ifadesinde bulunan $\hat{\imath}(ى)$ yukarıda örnekleriyle açılanmış olan işaret ya'sının kalıplaşmış şeklidir. Metinde çok sayıda kullanımı görülmektedir:

Yād ḳılğıl öz parvardıgārınnı vaḳtî kim özünni unutḳan bolsay. "Kendini unuttuğun vakitte kendi Tanrı'nı hatırla." (300a/3)

Buna karşıllı bazı kısımlarda bu tür cümlelerin Türkçenin sentaksına uygun olarak kurulduğu görülür:

Hudāy atını éltinizler kémeni sürer vaḳtda ve anı tohtatur vaḳtıda. "Gemiyi sürdüğünüz ve durduğunuz vakitte Tanrı'nın adını anın." (223b/5)

Zarf yardımcı cümlelerinde işaret ya'sının kalıplaşmasıyla kullanılan bağlama vasıtalarından biri de hālatîde kim olup onunla kurulan yardımcı cümleler ana cümledeki yüklemin ne şekilde yapıldığını veya olduğunu bildirir. Eserde çok sayıda kullanıldığı görülmektedir:

İninizler uçmaḩda ḥālatįde kim ḳarındaşlar bolġaysızlar biri biriniz bile. "Birbirinize kardeş olduğunuz şekilde cennete giriniz." (263b/18)

Tüşer öz inekleri bile yánî yüzlerige hāatatîde kim sacda ḳılġaylar hudāynıy buyuruġı ta'ẓîmi üçün. "Allah'ın buyruğuna tazim etmek için secde edecek şekilde çeneleri ile, yani yüzükoyun düşerler.” (295a/21)

\section{Zarf/Nesne ve Fiilin Yakınlık-Uzaklık Durumu}

Farsçada fiilin çeşitlerini inceleyen bilim adamları genel olarak üç çeşit, basit, önekli ve birleşik fiil olduğunu belirtmektedirler. (Rubinçik 2001: 197) Fiiller cümlenin sonunda zarf, nesne ögelerinden sonra gelirken bazı birleşik fiillerin 


\section{$J(\Theta)$}

arasına zarf veya nesneler girebilmektedir. Bu duruma göre zarf/nesne ögesi birleşik fiilin içinde bulunursa uzaklık durumu, birleşik fiilden önce gelirse yakınlık durumu meydana gelir. Metnimizde Farsçaya özgü olan birleşik fiillerin arasına zarf veya nesnenin girdiği uzaklık durumu Türkçe cümlelerde sıkça göze çarpmaktadır:

Ṭa ām yégüçi bile kim bismillāh aytmag̉an bolġay şirkat yémekde ḳlur. "Bismillah demeden yemek yiyen kişinin yemeğinde ortak olur." (305a/12).

Mayl ẓālımlarg̉a ḳılmayız. “Zalimlere meyletmeyiniz.” (232a/9)

Til calāl ni'matı ve malik muta'āl tasbîhığa açḳaylar. "Büyük nimeti ve yüce Melik tespihine dil açacaklar." (205a/20)

Yüz lūt 'alayhi's-salām évinin éşikige koydılar. "Lut aleyhisselam'in evine doğru gittiler.” $(228 \mathrm{a} / 4)$

Ve özige kélip élig yūsuf'nıy boynıġa saldı, andın soy élig yūsufnıy étekige urdı. "Ve kendine gelip Yusuf un boynuna sarıldı, ondan sonra Yusuf un eteğine elini sürdü.” (243a/2)

Şahrnıy aşrāfı bile yüz ġārg̉a kéltürdiler. "Şehrin önde gelenleri ile mağaraya doğru geldiler." (299a/2)

Anıy bedeninin tükleri baş tondın çıkardı. "Onun bedeninin tüyleri kaftanından baş çıkardı (yükseldi)." (243b/19)

Pes arḳa düşmanġa ḳıldııızlar ve uruşdın ḳayttıyızlar. "Sonra düşmana sırtınızı çevirdiniz ve savaştan döndünüz." (185b/13)

Aznı ḥaml yoḳluḳka ḳılġaylar. “Azı yokluğa hamlederler.” (195b/10)

Hîç kişi hālî ṣıfatıdın bolmag̉ay. "Hiçbir kişi sıfatından hali olmayacak.” (204a/10)

Yukarıdaki örneklerde şirkat ḳl-, mayl kıl-, til aç-, yüz koy-, élig sal-, élig ur-, yüz kéltür-, baş çlkar-, arka kıl-, haml ḳl- birleşik fiillerinin arasına zarf girmiştir. Özellikle yüz koy-, yüz kıl-, yüz keltür-, hāli bol- birleşik fiilleri metinde genel olarak uzaklık durumunda kullanılmıştır. Çok az örnekte ise yakınlık durumunda kullanıldı̆̆ı görülmektedir:

Yüz koyup érdük biz kan'ān'ġa. “Biz Kenan’a doğru gitmiştik.” (244a/25) 


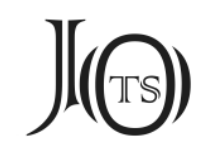

Yukarıda belirtilen dil özelliklerinin yanı sıra eserde bir yerde ayet tercümesinin bir kısmının doğrudan Farsça yapıldığı daha sonra Türkçesine değiştirildiği görülmektedir.

Eserin 184a sayfasının 5. satırından itibaren Tevbe suresi 17. ayeti başla-

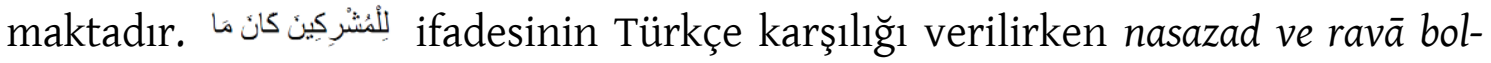
mag்ay müşrikin müşriklerge yazılmış daha sonra نسز ohşamas kelimesi onun üstüne yazılmıştır. نسز kelimesi Farsça sazîdan 'yaraşmak, yakışık olmak, uygun olmak' fiilinin geniş zaman olumsuzluk teklik III. şahıs çekimidir. Müstensihin ohşamas fiilinin yerine Farsçasını yazması da eserin Farsçadan çeviri olabileceği fikrini kanıtlamaktadır.

Bu tahmininden yola çıkılarak Farsça Kur'an tefsirleri ve tercümeleri tarafımızdan incelendi. Farsça tefsirler incelenirken Çağatayca tefsirin istinsah edildiği tarih önemli ipucu vermekteydi. Bu nedenle öncelikle eserin yazıldığı XVI. yüzyılda kaleme alınan veya o dönemde meşhur olan Farsça bazı tefsirlerle -Tercüme-i Tefsir-i Taberî, Tefsir-i Kuşeyrî, Keş̧ü'l-Esrar, Tefsir-i Yakub Çerhî, Cevahirü'tTefsir, Mevahib-i Aliyye (Tefsir-i Hüseynî)- karşılaştırmalarını yaptık.

Mukayeseler sonucunda Çağatayca (Doğu Türkçesi) Kur'an Tefsiri olarak bilinen eserin Farsça yazılan Mevahib-i Aliyye tefsirinin tercümesi olduğu tespit edildi. Tam adı el-Mevahibü'l-'Aliyye fi tefsîri'l-kelami'r-Rabbaniyye olan eser, daha yaygın adıyla Tefsir-i Hüseynî olarak anılır. Eser, Hüseyin Vâiz Kaşifî tarafından Hicrî 897-899 (1492-1494) yılları arasında Fars dilinde yazılmış muhtasar bir tefsirdir.

Tefsir-i Hüseynî, sadece Orta Asya ve Horasan bölgesinde değil bütün Müslüman ülkelerde ilgi görmüş ve çeşitli dillere tercüme edilmiştir. Günümüze kadar eserin Urduca, Peştuca, Tatarca, Osmanlıca ve Özbekçe çevirilerinin yapıldı̆̆ı bilinmekte idi. Elimizdeki tefsir ise eserin Çağatayca çevirisidir.

\section{Eserin Mütercimi, Yazılı̧̧ Tarihi ve Yeri}

Hüseyin Vaiz Kaşifî tefsirini Nevaî hayattayken 1494 yılında tamamlamıştır. Tefsir, İslam âleminde büyük ilgi görmüş, Hindistan'dan Altın Orda'ya, Kaş- 


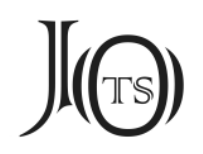

gar'dan Osmanlı devletine kadar yayılan coğrafyada okunmuş, çeşitli dillere tercüme edilmiştir. Bunda Hüseyin Vaiz Kaşifînnin kişiliğine duyulan güven, eserlerinde bulunan tasavvufî ve ahlakî eğilimlerin yanı sıra faaliyet gösterdiği muhite olan güven önemli rol oynamıştır. Dolaysıyla Çağatayca Mevahib-i Aliyye tercümesi, eserin yazılış tarihine çok yakın bir tarihte yapılmış olmalıdır.

Eserin bilinen nüshalarında Çağatayca'ya çeviren mütercimin adı, nerede ve ne zaman tercüme edildiğine dair herhangi bir kayıt bulunmamaktadır. Ancak istinsah tarihinden hareketle XVI. yüzyılın başında tercüme edildiği kesin olarak düşünülebilir. Çağatayca Mevahib-i Aliyye'nin en eski ve tam nüshası olan Topkap1 nüshası Hicrî 950 (1543) yılında istinsah edilmiştir.

Eserin yazıldığı XVI. yüzyılda Orta Asya ve Horasan'ın siyasî durumu çok hızlı değişmiştir. Şah İsmail'in Timurlulardan hükümdarlığı ele geçirmesinden çok geçmeden bölgede güçlenen Şeybanîler birer birer bölgelere hâkim olmaya başladılar. Şeybanî hükümdarlarından olan Ubeydullah Han Herat'i ele geçirdikten sonra başkent Buhara'ya diğer bölgelerden önemli sanatçıları, âlimleri ve ileri gelenleri getirmiş, faaliyetlerini Buhara'da devam ettirmelerini sağlamıştır. Türkçeye çok önem veren Ubeydullah Han, şiir yazmasının yanı sıra birçok önemli eseri Türkçeye çevirmiştir. Örneğin, kendisine Kur'an-1 Kerim kaidelerini öğreten Mevlâna Kemaleddin Yar Muhammed bin Mevlâna Hudaydad es-Semerkandî'nin Kavaidü'l-Kur'an adlı kitabını Terceme-i Kavaidü'l-Kur'an ve Fevaidü'l-Furkan adıyla Çağataycaya çevirmiştir. Tercümeyi bilim dünyasına tanıtan Ahmed ATEş, Ubeydullah Han'ın tercümenin giriş kısmında, Türk halkının Fars dilini bilmemesinden dolayı Kavaidü'l-Kur'an'ın Türkçeye çevrilmesinin yararlı olacağını yazdığını belirtmiştir (1964: 130).

Ayrıca tasavvufa olan eğiliminden dolayı tasavvuf cemaati arasında ilgi gören ve bir tasavvufî tefsir olan Tefsir-i Hüseynînin Türkçeye tercümesinin de Ubeydullah Han tarafından veya onun teşviki ile Kur'an bilgisi olan, Türkçe ve Farsçaya çok iyi vakıf olan bir yakını tarafından başkent Buhara'da yapıldığı düşünülebilir. 


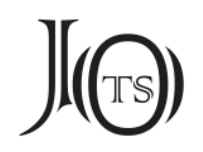

\section{Tefsir-i Hüseynînnin Osmanlı Türkçesine Tercümeleri}

Tefsir-i Hüseynî yazıldıktan yarım asır sonra Hicrî 952 (1546) yılında Selanikli Ali bin Veli tarafından Tercemetü Tefsiri'l-Mevahibi'l-Aliyye (Tercüme-i Tefsir-i Hüseyin el-Kaşifî) adıyla Türkçeye çevrilmiştir. Abdülhamit BỉişıK bu tercümenin Kur'an tefsirinin ilk Türkçe çevirisi olduğunu tahmin etmektedir (2004: 63). Ancak çalışmamızın konusu olan Tefsir-i Hüseynînnin Çağatayca tercümesinin Topkapı nüshası Hicrî 950 (1543) yılında istinsah edildiğine göre ilk tercümenin Çağatay Türkçesi ile yapıldı̆̆ı anlaşılmaktadır. Selanikli Ali bin Veli'nin Osmanlıca tercümesi iki cilt halinde yapılmış olup nüshaları İshak Paşa ve Süleymaniye kütüphanelerinde bulunmaktadır. Aşağıda verilen karşılaştırmalı metinde Selanikli Ali bin Veli'nin tercümesinden yararlandık.

Bu çeviriden sonra meşhur İdris-i Bitlisînin oğlu olan Ebü'l-Fazl Mehmed Efendi (öl. 982/1574) de Tefsir-i Hüseynî eserini Osmanlıcaya tercüme etmiştir. Tercümenin nüshaları İstanbul Üniversitesi Nadir Eserler Kütüphanesi ve Çorum Il Halk Kütüphanesinde muhafaza edilmektedir. Ancak Ebü'l-Fazl Mehmed Efendi, Mevahib-i Aliyye tefsirini Çağatay Türkçesine yapıldığı gibi ağırlıklı olarak birebir aktarmamış, bazen ilaveler yaparak bazen de özet bir şekilde tercüme etmiştir.

Ayrıca Osmanlı Türkçesine 1635 yılında Şeyh Ömer Adulî Niğdevî tarafından da çevrilmiş olup iki cilt halinde Süleymaniye Kütüphanesinde korunmaktadır. Aslen Kırımlı olan İsmail Ferruh Efendi (öl. 1256/1840), Mevahib-i Aliyye tefsirini Mevakib adıyla tercüme etmiştir. Müellif nüshası İstanbul Üniversitesi Nadir Eserler Kütüphanesinde bulunmaktadır. Osmanlı devletinin son yıllarında yapılan bu tercüme dili, üslubu, muhtevası sebebiyle büyük ilgi toplamış ve farklı yayınevleri tarafından Tefsir-i Mevakib Tercüme-i Mevahib-i Aliyye, Mevakib Tercüme-i Tefsir-i Mevahib, Mevakib Tefsiri, Tercüme-i Tefsir-i Mevahib gibi isimlerle birçok kez basılmıştır. Halk arasında çok rağbet gören tercüme Cumhuriyet döneminde Süleyman FAHiR tarafından sadeleştirilmiş ve Latin harfleriyle Mevakib Tefsiri Kur'an-ı Kerim ve Meali adıyla iki ciltli olarak basılmıştır (1959).

Tahirü'l-Mevlevî (1877-1951) ise Mevahib-i Aliyye tefsirinin Bakara suresinin sonuna kadar olan kısmını Türkçeye çevirmiştir. İsmail Farruh Efendi'nin Meva- 


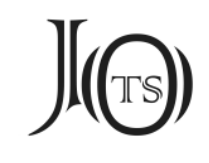

kib tercümesinde bazı eksiltmeler ve ilaveler bulunduğunu belirterek birebir tercüme gerektiğini vurgulayan Tahirü'l-Mevlevî Hindistan baskısını esas alarak çeviri yapmıştır $(1909,1912)$.

Kazanlı Muhammed Sadık İmankulı Mevahib-i Aliyye tefsirini Teshilül-Beyan Fi Tefsiri'l-Kur'an adıyla Tatar Türkçesine tercüme etmiştir. Çeviri 1900-1910 yılları arasında yazılmış ve Kazan'da ilk olarak 1911 yılında iki ciltli olarak basılmıştır. Birinci cilt Fatiha suresi ile başlayıp İsra suresi ile bitmekte, ikinci cilt Kehf suresi ile başlayıp Nas suresi ile tamamlanmaktadır. Muhammed Sadık İmankulı tefsirin birebir çevirisini yapmakla birlikte, haşiye kısmında bazı açıklamalar ve ayetin nüzul sebebi gibi birtakım bilgiler vermiştir. (1996) Bu tercüme üzerinde Gayaz AKHMETSHiN yüksek lisans tezi hazırlamıştır. (2012)

Ayrıca Afganistan, Hindistan, İran, Mısır, Rusya gibi ülkelerde eserin birçok kez taşbaskısı yapılmıştır.

Çağatayca Kur'an tefsirinin, Tefsir-i Hüseynînin tercümesi olduğu tespit edildikten sonra dünya kütüphanelerinin kataloglarından diğer nüshalarını araştırdık. Bu zamana kadar eserin Konya (Konya Karatay Yusuf Ağa Kütüphanesi, No: 42 YU 6624) ve Topkapı (III. Ahmet Bölümü, No: 16) nüshaları bilinmekteydi. Araştırmaların neticesi olarak Özbekistan Cumhuriyeti İlimler Akademisi Ebu Reyhan Birunî adlı Şarkşinaslık Enstitüsünün yazma eserler kütüphanesinde Tefsir-i Hüseynî Tercümesi adı ve 7455 arşiv numarasıyla muhafaza edilen üçüncü nüsha tespit edildi. Taşkent nüshası XIX. yüzyılda istinsah edilmiş olsa da Klasik sonrası Çağatayca dil özelliklerini yansıtmamaktadır. Karşılaştırmalar neticesinde Taşkent nüshasının, bazı küçük farklılıklar dışında büyük ölçüde Topkapı nüshası ile aynı olduğu tespit edilmiştir.

\section{Farsça ve Çağatayca Tefsir-i Hüseynî̉nin Karşılaş̧ırması}

Farsça Tefsir-i Hüseynî ve Çağatayca tercümesini karşılaştırırken ilk olarak şekil benzerlikleri dikkat çekmektedir. Farsça Tefsir-i Hüseynî nüshaları genelde iki ciltli olarak yazılmış olup birinci ciltler Fatiha suresinden başlayıp Kehf suresinin sonuncu ayetiyle biter, ikinci ciltler ise Meryem suresinden başlayıp Kur'an-1 Kerim'in son ayeti Nas suresiyle biter. Kur'an ayetlerinin üstü çizilerek 


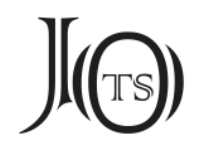

metinden ayrilır, sure isimleri siyah veya mavi mürekkeple yazılır. Ayetlerin tamamı veya belirli kısmı tercüme edildikten sonra tefsirli açıklamalar, hadisler, diğer tefsirlerden örnekler, zaman zaman kıraat farklılıkları gösterilir. Bunun gibi durumlar eserin Çağatayca tercümesinde de aynı şekilde görülmektedir. Ancak Farsça nüshaların bazılarında bir sayfalık mukaddime kısmı bulunurken Türkçe nüshalarda yoktur.

Aşağıda Çağatayca ve Farsça Tefsir-i Hüseynî nüshalarının bazı kısımlarından karşılaştırmalar verilmektedir. Çağatayca metin için Topkapı nüshası, Farsça metin için İran Milli Kütüphanesinde 11959 numarayla muhafaza edilen nüsha, Osmanlı Türkçesi metninde ise Süleymaniye Kütüphanesi Hacı Mahmud Efendi Koleksiyonunda bulunan 255 numaralı nüsha esas alınmıștır. Bütün nüshalar XVI. yüzyllda istinsah edilmiştir.

\begin{tabular}{|c|c|}
\hline Çağatay Türkçesi & Farsça \\
\hline 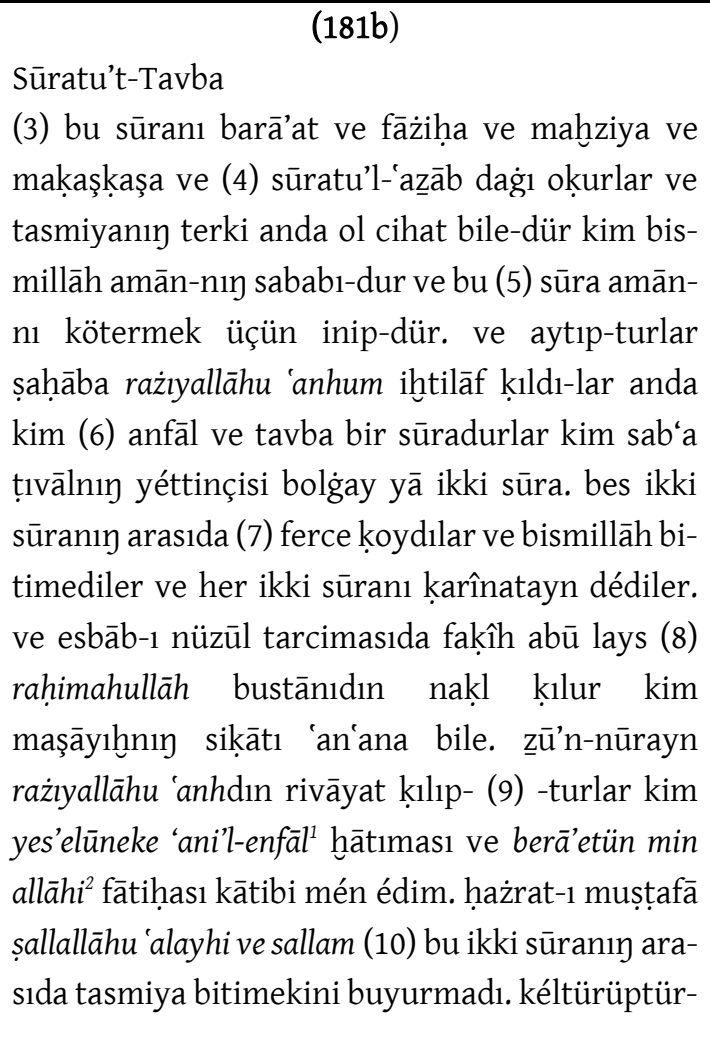 & 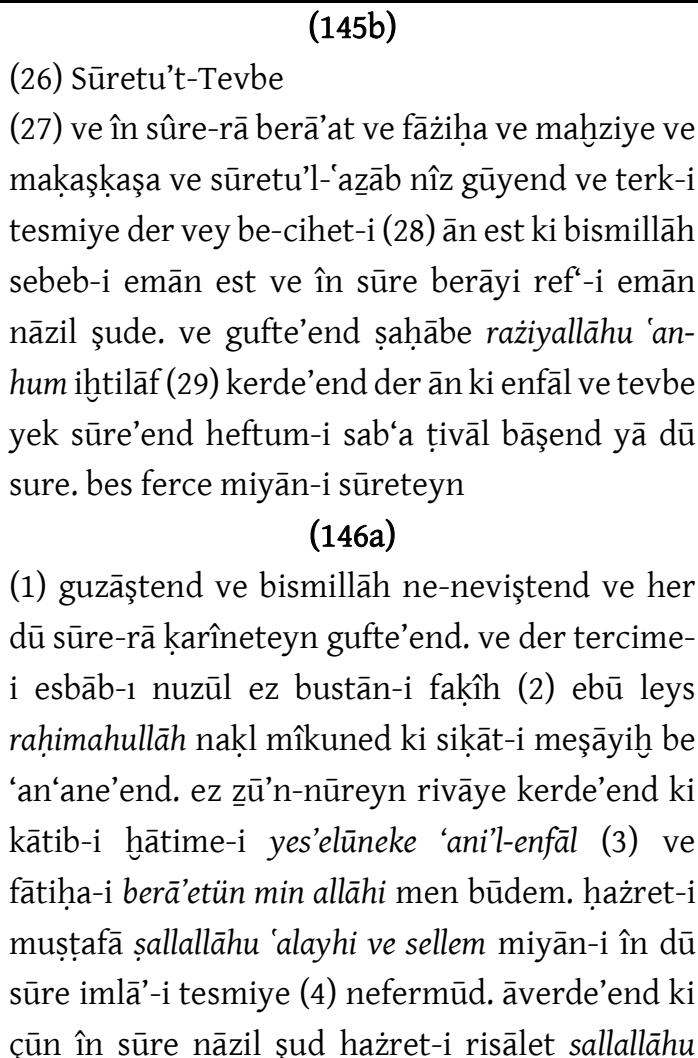 \\
\hline
\end{tabular}

\footnotetext{
1 Sana savaş ganimetlerini soruyorlar. (Enfal 1)

2 Allah'tan bir ihtardır. (Tevbe 1)
} 
ler çün bu sūra nāzil boldı hażrat-ı risālat (11) șallallāhu 'alayhi ve sallam otuz yā ḳırk āyat sūranıy avval-larıdın abū bakr rażıyallāhu 'anhġa bérip anı hācnı̀ amîri (12) ḳıldı ve buyurdı kim mavsim ahlig̉a oḳugay. ve néçe kün șıddîk rażıyallāhu 'anhnıy bargaanıdın soy murtażā 'alî (13) rażıyallāhu 'anhnı tiledi ve gażaba nāḳasıg̉a mindürüp abū bakr rażyyallāhu 'anhnıy soyıdan yiberdi ve buyur- (14) - d1 kim āyatlarnı andın alıp özi oḳugay. ve çün uşbu hāldın sordılar cavāb bérdi kim cibrîl (15) mana kéldi ve ayttı: "bu payġāmnıy adāsını ḳılmag̉ay meger sén yā kişi kim séndin bolgay." pes 'alî, abū bakr rażıyallāhu 'anhumā- (16) -ġa ulandı ve tarviya künide șıddîk rażıyallāhu 'anh hutḅba oḳudı ve kişilerge manāsiknin ta'lîmini ayttı ve naḥr (17) künide 'alî rażıyallāhu 'anh camra-yı 'aḳaba ḳaşıda āyatlarnı mevsim ahlıga oḳudı.

(Bk. Resim I) 'alayhi ve sellem sî yā çihl āyet ez evvel-i sūre (5) be ebū bekr șiddîk rażiyallāhu anh dāde ū-rā emîr-i hāāc sāĥt ve fermūd ki ber ehl-i mevsim h้̄āned. ve be çend rūz ba'd ez (6) reften-i șiddîk, murtażā 'alî rażiyallāhu 'anhumā țaleb fermūd ve nāḳe-i gazạaba sevār sāhnt ve ez 'aḳab-i ebū bekr ferestād (7) ve emr kerd ki āyāt-rā ez vey gerefte hūud kirā'at kuned. ve çūn ez ez în hāal pursîdend cevāb dād ki cibrîl be-men âmed (8) ve guft: “edā-i în peygāām nekuned meger tū yā kesî ez tū bāşed." pes 'alî be ebū bekr rażiyallāhu 'anhumā lāhị şud ve der rūz-i terviye (9) șiddîk rażiyallāhu 'anh huțe h hāand, merdumān-rā ta'lîm-i menāsik fermūd ve der rūz-i nahr 'alî kerremallāhu veche nezdîk-i (10) cemre-i 'aḳaba āyethā-rā ber ehl-i mevsim ḩ ${ }^{\vee} a \bar{n} d$.

(Bk. Resim II)

Kehf suresi 9. ayetinin Çağatay ve Osmanlı Türkçesiyle yapılan tercüme tefsirlerini Farsça aslı ile karşılaştıralım:

\begin{tabular}{|c|c|c|}
\hline Çağatay Türkçesi & Osmanlı Türkçesi & Farsça \\
\hline 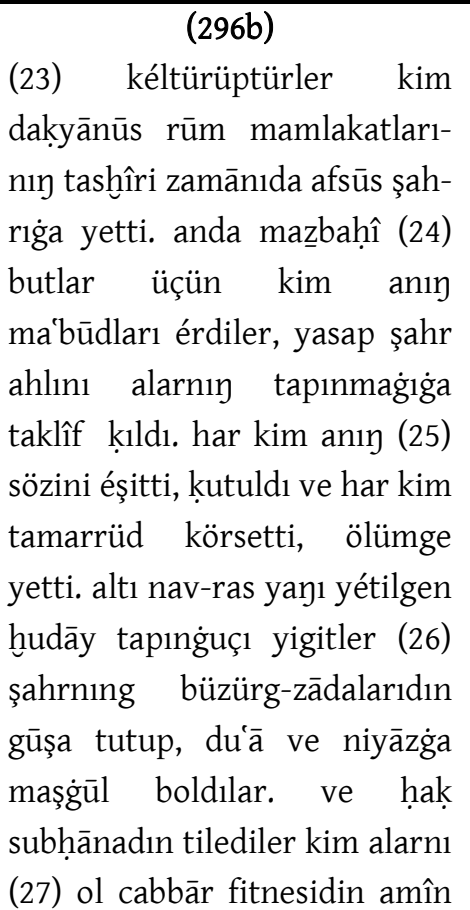 & 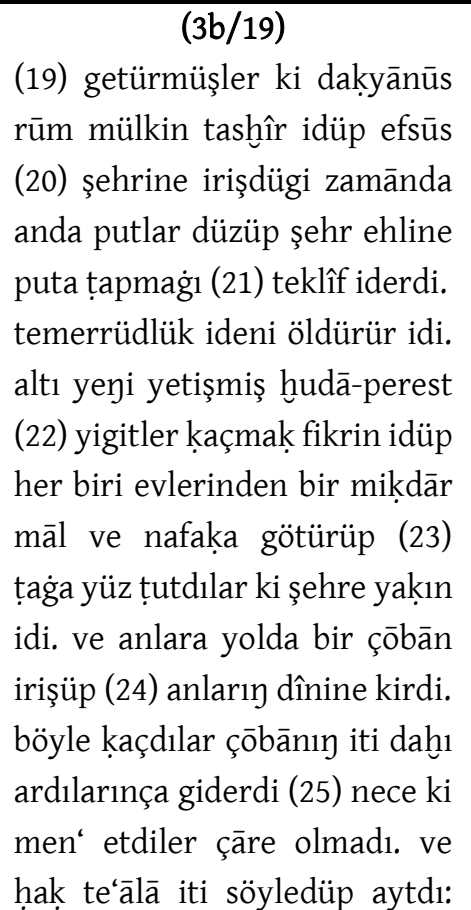 & 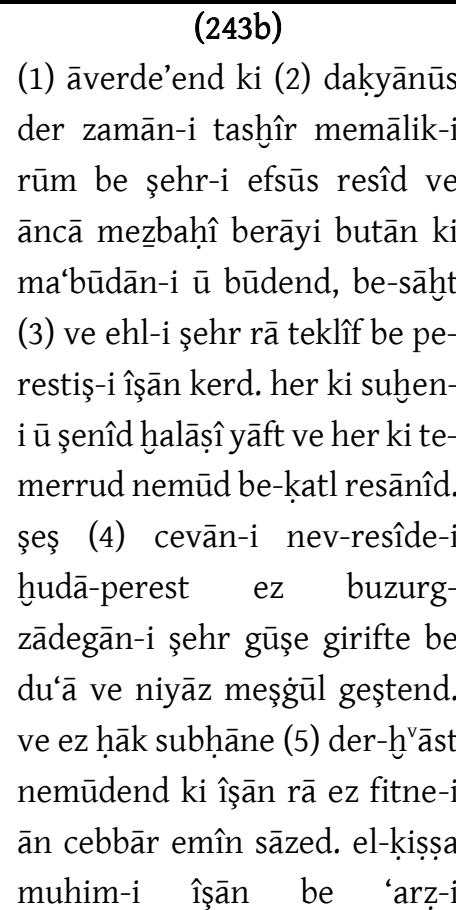 \\
\hline
\end{tabular}


ḳılg̀ay. al-ḳıșșa alarnın işi dakyānūs 'arżığa yetti ve alarnı ḥāżır ḳılmaḳ buyurup,

(297a)

(1) korkutmak köp körsetti. alar tavhîd țarîkıga bérklik körsetip muṭlaḳā anı farmānını kabūl kıılmadılar. dakyānūs buyurdı (2) tā hullî̀ve hulal kim alarnın boylarıda érdi, tartıp aldı-lar ve ayttı: "sizler kiçig yaşligsizler. Sizlerge ikki üç kün (3) muhlat bérdim tā öz işinizde ta'ammül ḳlġaysızlar ve körünizler kim sizlernin maṣlahatııız ménin sözümnin (4) kabūlıdadur yā anıy raddıda." Pes ol şahrdın özge yerîge yüzlendiler ve yigitler anı barġanını ganîmat bilip biri biri bile (5) öz işinin bābıda kéyeş ḳıldılar ve barçasınıy kéneşi kaçmaḳka karār taptı. Har biri öz atasını évidin az (6) māl azuk ve nafaḳa üçün köterip, yüz tağig̀a kim şahrnıy yavuġıda érdi, kéltürdiler. Yolda çobanî alarǵa yétti ve alar- (7) -nıy dînige kirip murāfaḳatda muvāfaḳat körsetti. çobannıy iti dağı alarnıy soyıda yügüre başladı. ve ança kim (8) kaytardılar, kaytmadı ve hudāy anı sözge kéltürdi tā faṣ̂h til bile ayttı: “méndin korkmanızlar kim mén hudāynı̀ (9) dōstlarını dōst tutarmén. sizler uyḳuğa barsayızlar tā mén sizlerni saḳlavçılık ḳlurmén."

(Bk. Resim III)
(26) "siz benden korkman ki ben tanrı dōstların șaḳlar ben. uyumakgga gidersiz pāsbānlık iderim." didi.

(27) (Bk. Resim IV) dakyānūs resîd ve be iḥzār-i (6) îşān emr kerde tehdîd-i bisyār nemūd. îşān ber țarîk-i tevhîd rusūh verzîde muțlakā fermāni ū kabūl nekerdend. dakyānūs (7) befermūd tā hullî ve hulel ki ber-dāştend ez îşān intizā kerdend ve guft: "şumā cevānānîd ve huurd sāl. şumā rā dū se rūzî (8) muhlet dādem tā der kār-i hūd te'emmul kunid ve bebînîd ki mașlahat-i şumā der kabūl-i kavl-i men est yā der redd-i ān." pes, ez ān şehr (9) muteveccih mevzii'-i dîger şud ve cevānān reften-i ū-rā ganîmet dāneste bā yekdîger der bāb-i muhimm-i hūd muşāveret nemūdend ve rey-i (10) heme [firār] karār yāft. her yek ez hāne-i peder kadrî māl be-cihet-i zād ve nafaka ber-dāște rūy be kūhî ki nezdîk-i (11) şehr būd āverdend. ve der rāh şubānî bedîşān resîd ve be dîni îşān der-āmede der murāfakat muvāfakat nemūd. seg-i (12) şubān nîz ber 'aḳab-i îşāan devîden āgaāz kerd. çendān ki men' kerdend mumteni' neşud ve hudāy ū-rā be suhen āverd tā be zebān-i (13) fașị̂ guft: "ez men metersîd ki men dūstān-i hudāy rā dūst mîdārem. şumā der ḩvāb revîd tā men şumā rā pāsbānî kunem." (Bk. Resim V) 


\section{$J(\Theta)$}

\section{Sonuç}

Hüseyin Vaiz Kaşifî̀nin döneminin en önemli şahsiyetlerinden biri olan Ali Şir Nevâ̂’ye karşı sevgisi ve minneti çok yüksektir. Hüseyin Vaiz, gösterdiği ilgi ve yardımlarının dışında ilmine ve kişiliğine hayran olduğu Ali Şir Nevaî̀ye birçok eserini ithaf etmiştir. Örneğin, Mevahib-i Aliyye, Cevahirü't-Tefsir, Risaletü'lAliyye Fi Ehadisü'n-Nebeviyye, Mahzenü'l-İnşa' gibi eserleri Ali Şir Nevâ̂’ye ithaf edilmiştir. Hüseyin Vaiz Kaşifî bu eserleri Fars dilinde kaleme almıştır. Ancak Türkçeye çok önem veren ve eserlerini bu dilde yazan dönemin en önemli ve tanınmış edebî kişiliği olan Ali Şir Nevaî̀ye ithafen yazılan Farsça eserlerin Türkçeye çevrilmesi de doğal olarak çok erkenden yapılmıştır.

Bugüne kadar müfessiri ve kaynağı tespit edilemeyen ve Çağatayca (veya Doğu Türkçesi) Kur'an tefsiri olarak kayıtlara geçen, Konya ve Topkapı olmak üzere iki nüshası bilinen eser, aslında Tefsir-i Hüseynî adıyla daha çok tanınan $M e-$ vahib-i Aliyye adlı eserin tercümesidir. Mütercim eseri Farsçadan Çağatay Türkçesine çevirirken birebir tercüme etmeyi tercih etmiştir. Hatta Farsça aslında mevcut olan teşbih, telmih, mecaz ve deyimlerin de Çağataycaya aynen, birebir çevrildiği dikkat çekmektedir. Hicrî 952 (1546) y1lında Selanikli Ali bin Veli tarafından Osmanlı Türkçesine yapılan çevirisi ise eserin özet çevirisi mahiyetindedir.

Bütün bunlarla birlikte tefsirin Çağatay Türkçesi ve Osmanlı Türkçesine yapılan çevirilerinin birçok açıdan karşılaştırılması Türkolojinin pek çok alanı için faydalı olacaktır.

\section{Kaynakça}

AкHMETshin, G. (2012). Muhammed Sadık İmankuli ve Tefsiri Teshîlu'l-Beyan, Ankara Üniversitesi Sosyal Bilimler Enstitüsü, Temel İslam Bilimleri Anabilim Dal, Tefsir Bilim Dalı, Ankara. [Yayımlanmamış Yüksek Lisans Tezi]

Ateş, A. (1964). “Ubeydullah Han'ın Bilinmeyen Mensur Bir Eseri: Tarcama-i Ḳavāid al-Ḳur'ān va Favā’id al-Furḳan”, Türk Dili Araştırmaları Yıllığı Belleten 1964: 127-147.

BANGi, İ. (1971). Farsça Dil Bilgisi (Grameri), Ankara: Ankara Üniversitesi Yayınları. 


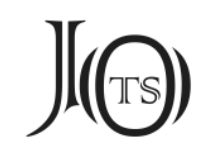

Bírş̧וK, A. (2004). “Osmanlıca Tefsir Tercümeleri ve Hüseyin Vâiz-i Kâşifî̀nin Mevâhib-i Aliyye'si”, İslâmî Araştırmalar, 17/1: 53-68.

ÇAĞLAR, D. (2013). Doğu Türkçesi Kur'an Tefsiri (Şuara ve Neml Sureleri), İnceleme-Tenkitli Metin-Dizin-Tıpkıbasım, Marmara Üniversitesi, Türkiyat Araştırmaları Enstitüsü, Türk Dili ve Edebiyatı Anabilim Dalı, Türk Dili Bilim Dalı, İstanbul. [Yayımlanmamış Yüksek Lisans Tezi]

EcKmann, J. (1967). “Doğu Türkçesinde Bir Kur’an Çevirisi (Rylands Nüshası)”, Türk Dili Araştırmaları Yıllı̆̆ı Belleten 1967: 51-69.

ERGiN, M. (2000) Türk Dil Bilgisi, İstanbul: Bayrak Yayınları.

FAHiR, S. (1959). Mevakib Tefsiri Kur'an-1 Kerim ve Meali, İstanbul: Bütün Kitabevi.

İMANKULI, M. S. (1996). Teshîlü'l-Beyan fi Tefsirü'l-Kur'an, Doha: Matabigu Katari'lVataniyye.

İNAN, A. (1963). “Şeybanlı Özbekler Çağına Ait Bir Çağatayca Kur’an Tefsiri”, Türk Dili Araştırmaları Yıllığı Belleten 1962: 61-66.

KuRToĞLu, K. (2015). Doğu Türkçesi Kur'an Tefsiri (Lukmān, Secde ve Ahzāb Sureleri), İnceleme-Tenkitli Metin-Dizin-Tıpkıbasım, Marmara Üniversitesi, Türkiyat Araştırmaları Enstitüsü, Türk Dili ve Edebiyatı Anabilim Dalı, Türk Dili Bilim Dalı, İstanbul. [Yayımlanmamış Yüksek Lisans Tezi]

PeKGöz, G. A. (2016). Doğu Türkçesi Kur'an Tefsiri (Sebe, Fâtır ve Yasin Sureleri), İnceleme-Tenkitli Metin-Dizin-Tıpkıbasım, Marmara Üniversitesi, Türkiyat Araştırmaları Enstitüsü, Türk Dili ve Edebiyatı Anabilim Dalı, Türk Dili Bilim Dalı, İstanbul. [Yayımlanmamış Yüksek Lisans Tezi]

RuBinçiK, A. Y (2001). Grammatika Sovremennogo Persidskogo Literaturnogo Yazıka, Moskva: Vostoçnaya Literatura FAN.

TAhiRÜ’L-MeVlevi (1909). “K1sm-1 Mahsûs Tefsir-i Hüseynî'den Sûre-i Fâtiha Tercümesi”, Mihverü'l-Ulûm, 5: 79.

TAhiRü'L-MeVlevi (1912). “Kısm-1 Mahsûs-Tercüme-i Tefsir -i Hüseynî'den Sûretü'l-Bakara", Mihverü'l-Ulûm, 7: 111-112.

TAş, İ. (2001). Çağatayca Kur'an Tefsiri 21a-41b (Giriş-Metin-Dizin), Marmara Üniversitesi, Türkiyat Araştırmaları Enstitüsü, Türk Dili ve Edebiyatı Anabilim Dalı, Türk Dili Bilim Dalı, İstanbul. [Yayımlanmamış Yüksek Lisans Tezi] 


\section{$J(\Theta)$}

TEkin, Ş. (1992). “Eski Türkçe”, Türk Dünyası El Kitabı II, Türk Kültürünü Araştırma Enstitüsü Yayınları, Ankara: 142-192.

Temel, E. (2013). Doğu Türkçesi Kur'an Tefsiri (Nur ve Furkan Sureleri), İncelemeTenkitli Metin-Dizin-Tıpkıbasım, Marmara Üniversitesi, Türkiyat Araştırmaları Enstitüsü, Türk Dili ve Edebiyatı Anabilim Dalı, Türk Dili Bilim Dalı, İstanbul. [Yayımlanmamış Yüksek Lisans Tezi]

UzunoĞLu, H. Ş. (2015). Doğu Türkçesi Kur'an Tefsiri (Ankebut ve Rum Sureleri), İnceleme-Tenkitli Metin-Dizin-Tıpkıbasım, Marmara Üniversitesi, Türkiyat Araştırmaları Enstitüsü, Türk Dili ve Edebiyatı Anabilim Dalı, Türk Dili Bilim Dalı, İstanbul. [Yayımlanmamış Yüksek Lisans Tezi]

ÜNGöR, Y. A. (2015). Doğu Türkçesi Kur'an Tefsiri (Sâffât, Sad ve Zümer Sureleri), İnceleme-Tenkitli Metin-Dizin-Tıpkıbasım, Marmara Üniversitesi, Türkiyat Araştırmaları Enstitüsü, Türk Dili ve Edebiyatı Anabilim Dalı, Türk Dili Bilim Dalı, İstanbul. [Yayımlanmamış Yüksek Lisans Tezi]

Yelten, M. (2005). “Pars-Name'deki Ki'li Birleşik Cümleler Üzerine”, Modern Türklük Araştırmaları Dergisi, 2/4: 45-56.

ZÜLFiKAR, H. (1974). “Çağatayca Bir Kuran Tefsiri”, Türkoloji Dergisi, 4/1: 153-195. 


\section{J(৫)}

\section{Resimler}

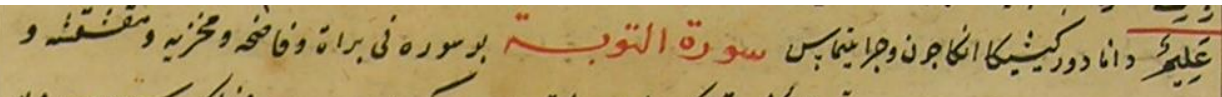

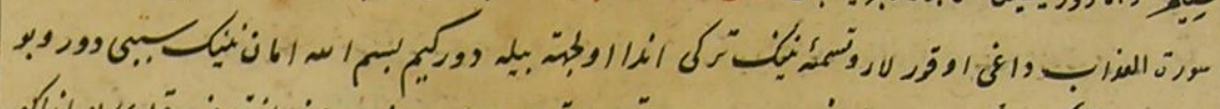

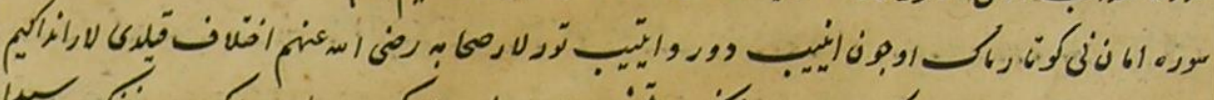

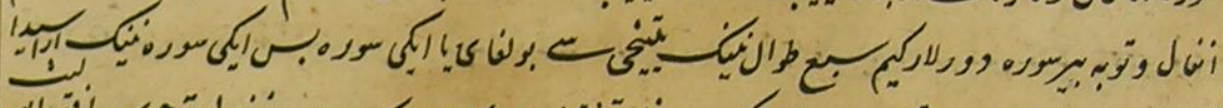

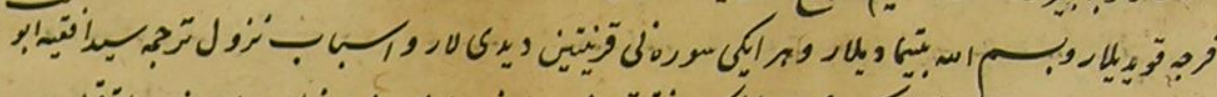

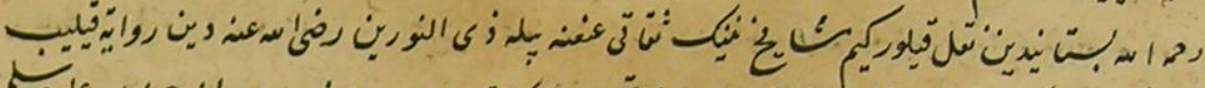

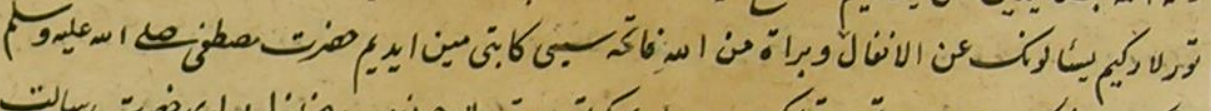

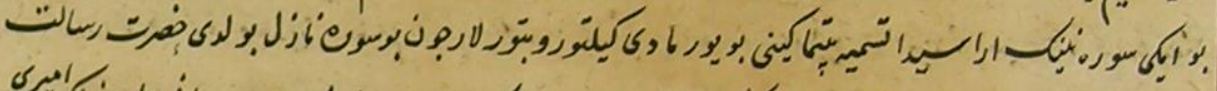

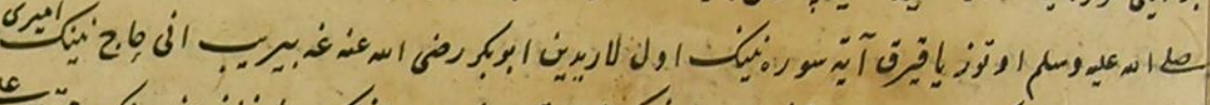

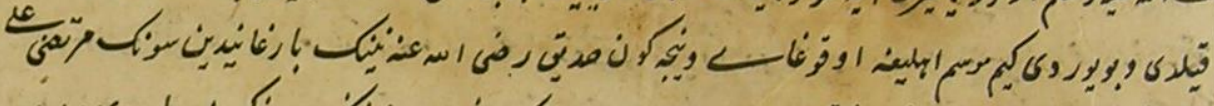

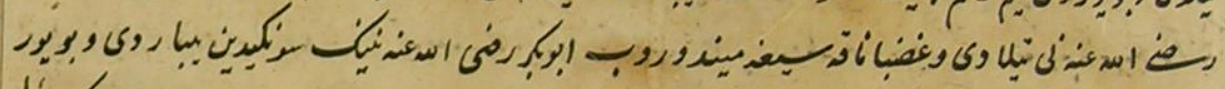

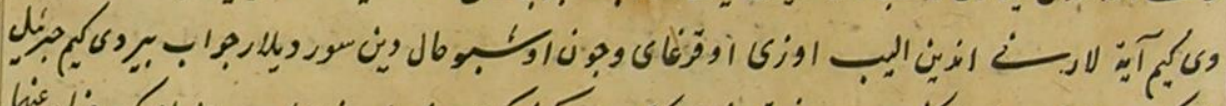

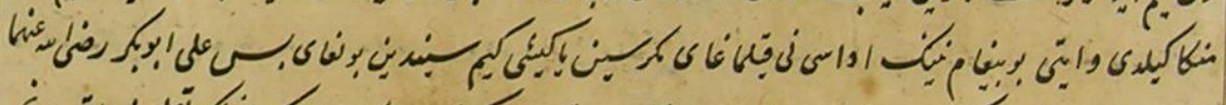

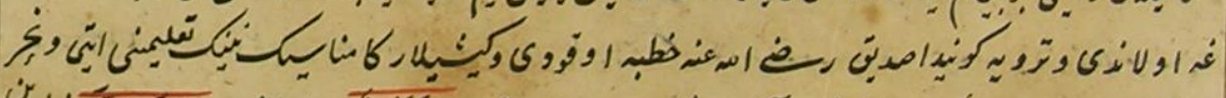

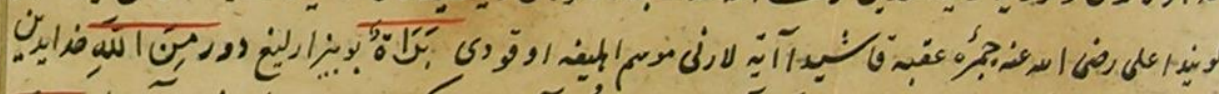

Resim I

Çağatayca Yazma (181b/3-17) 


\section{J(G)}
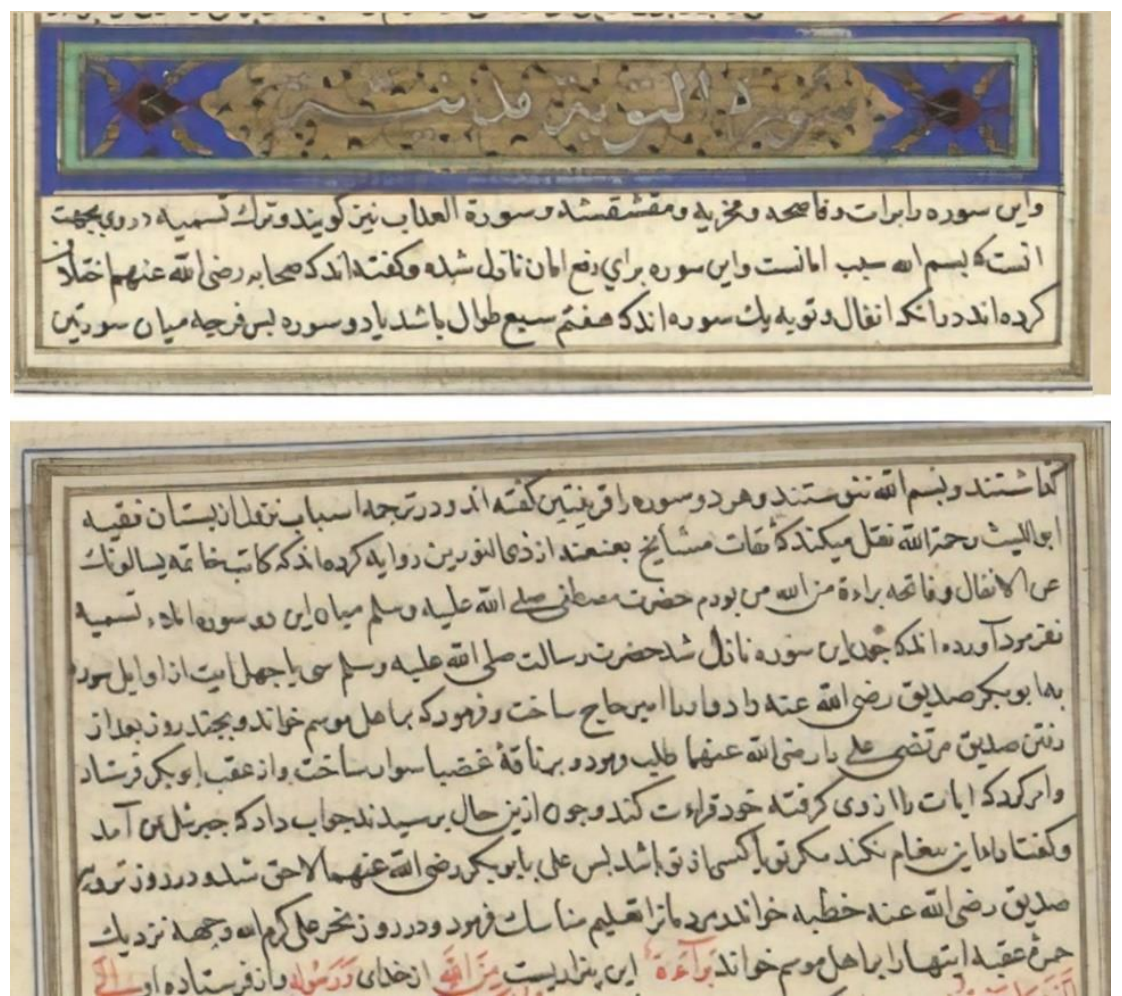

Resim II

Farsça Yazma (145b/26-146a/10)

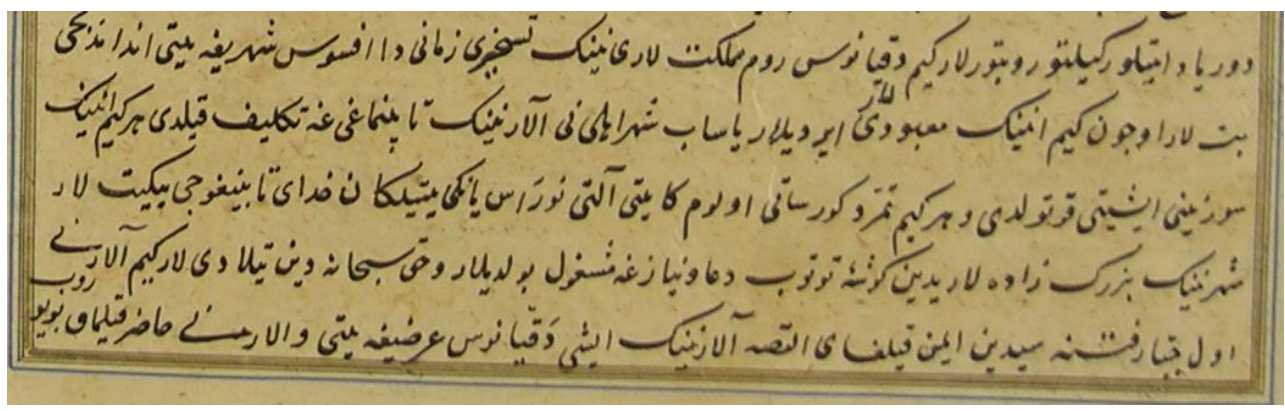




\section{J(৫)}

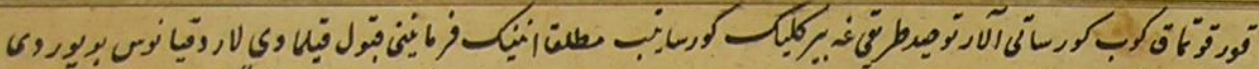

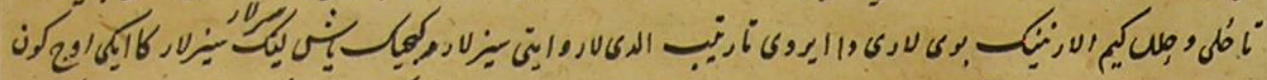

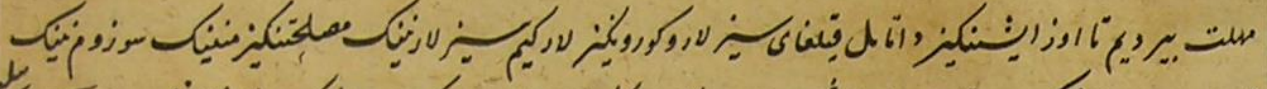

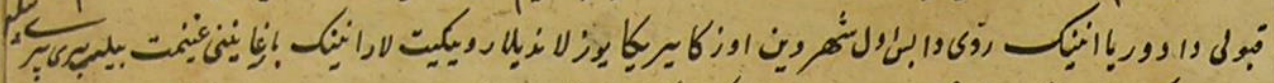

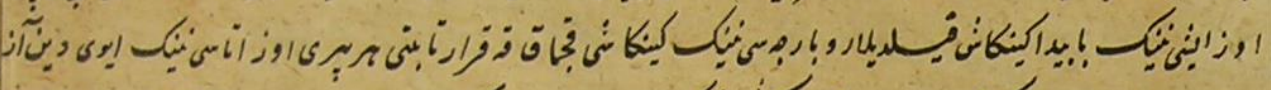

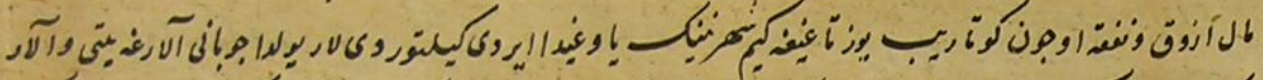

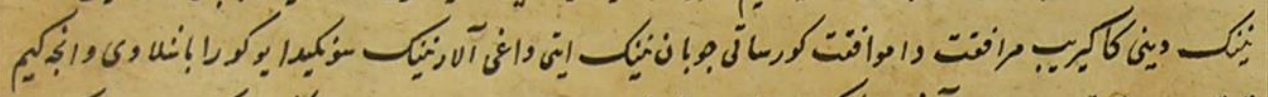

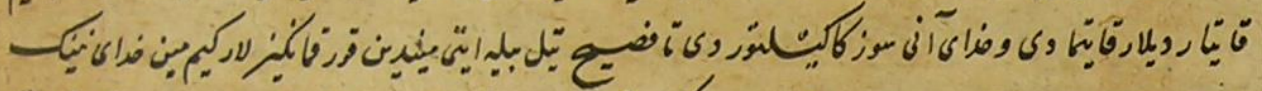

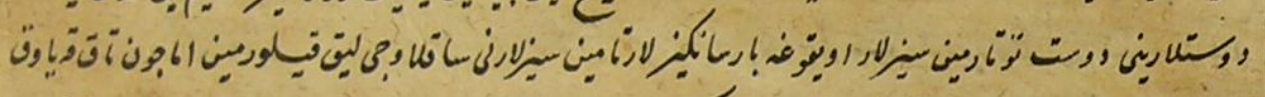

\section{Resim III}

Çağatayca Yazma (296b/23-297a/9)

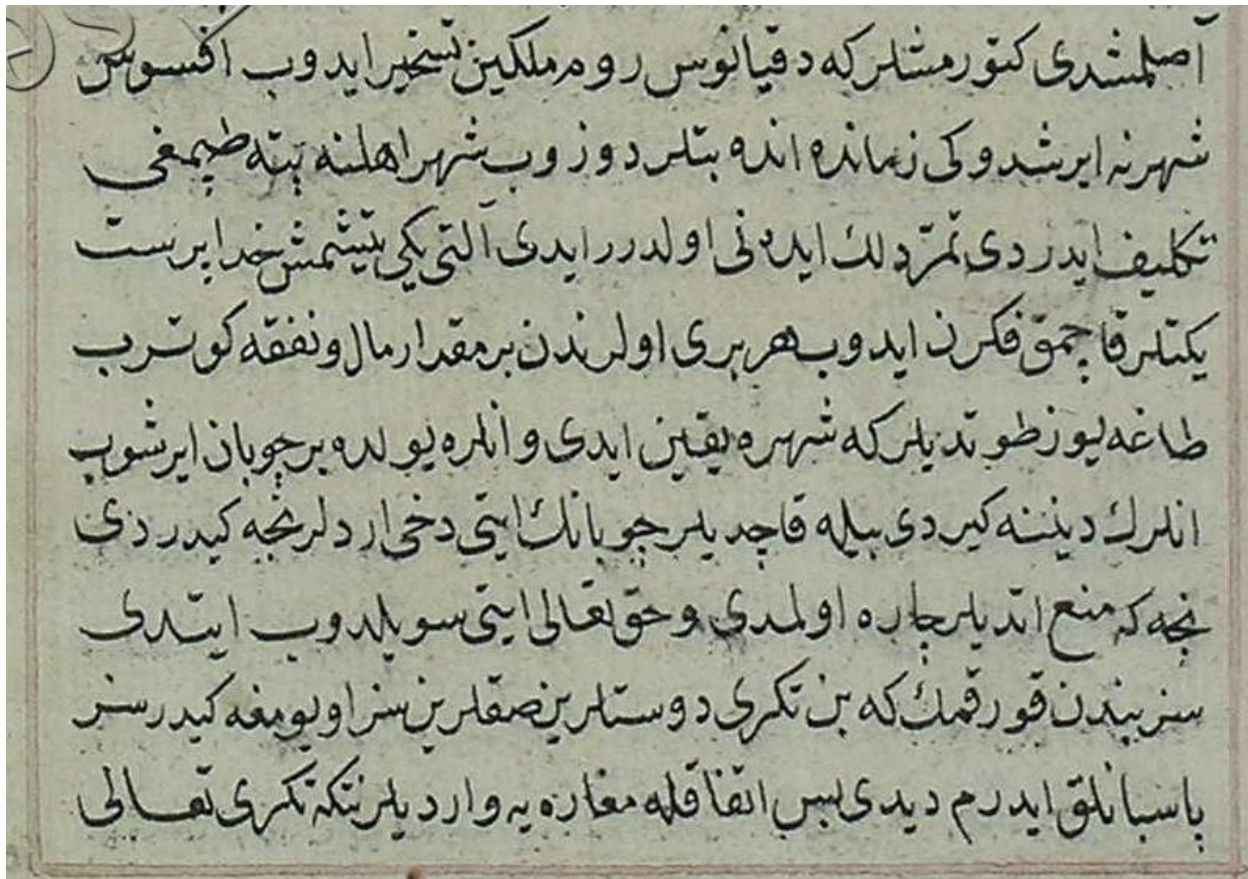

Resim IV

Osmanlıca Yazma (3b/19-27) 


\section{J(৫)}

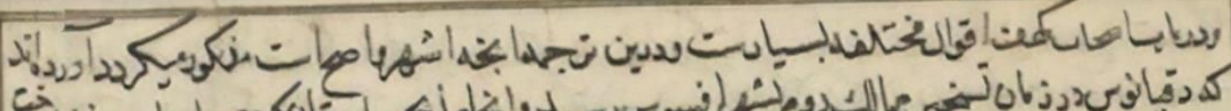

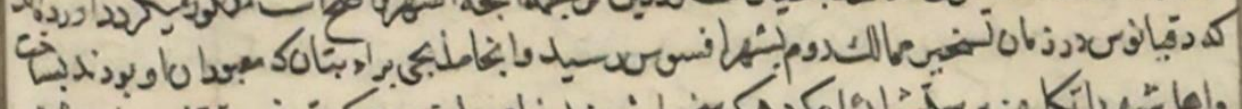

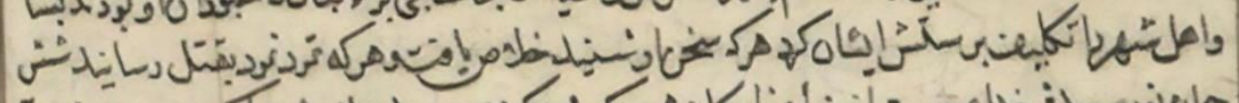

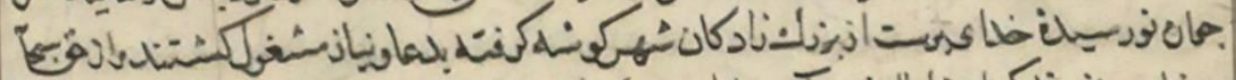

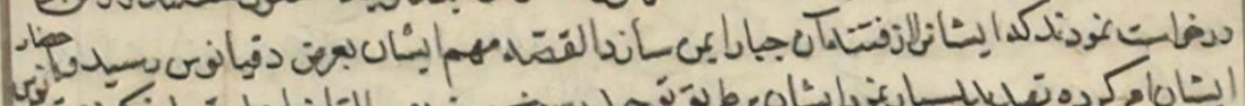

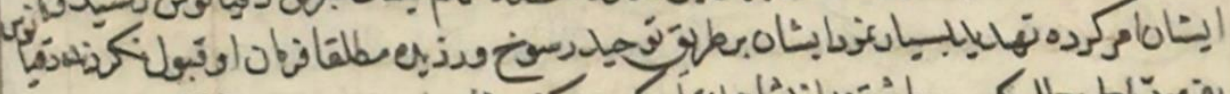

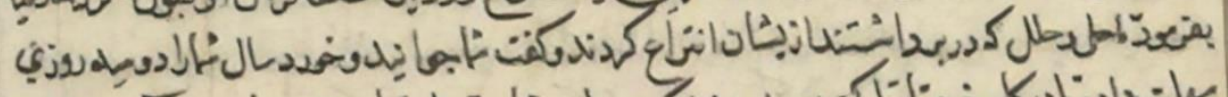

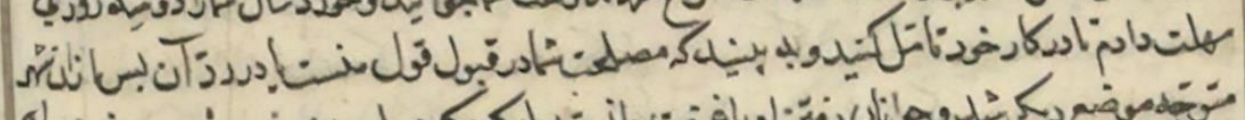

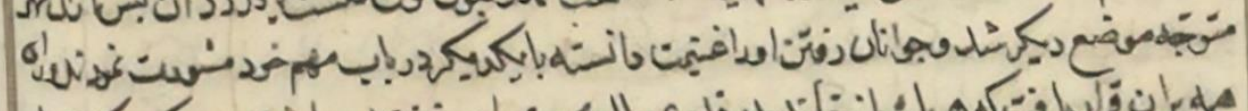

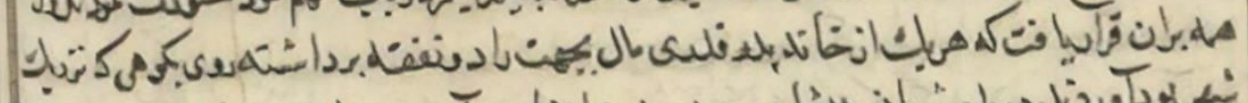

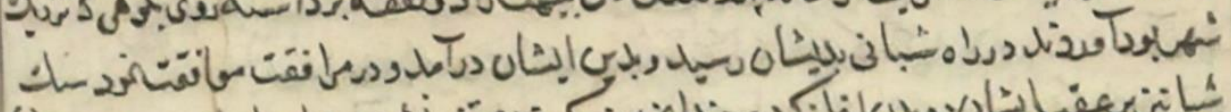

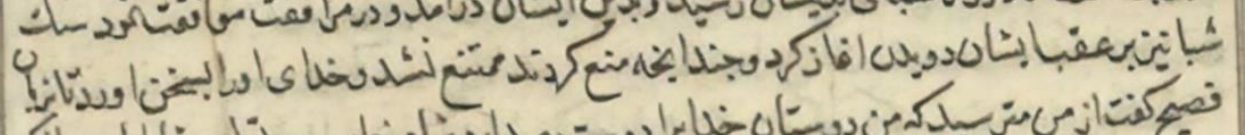

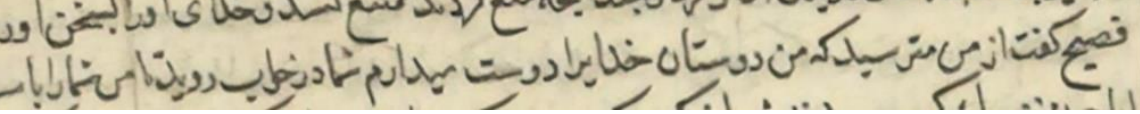

Resim V

Farsça Yazma (243b/1-13) 